\title{
Study of the Impact of Private Equity on the Listed Companies' Earnings Management
}

\author{
Wei $\mathrm{He}^{1, *}$ and Yuling Liao \\ ${ }^{I}$ School of Finance and Statistics, Hunan University, Changsha, Hunan, 410006, China ${ }^{2}$ Department of Legal and Pub- \\ lic Administration, Hunan University of Finance and Economics, Changsha 410205, China
}

\begin{abstract}
Based on the GEM 355 listed companies during the period October 2009 to December 2013, this paper provides an empirical analysis of the impact of private equity on earnings management among the GEM listed companies by introducing a modified Jones model and a multivariate linear regression model. The results suggest that Companies listed on GEM have positive earnings management behavior, But PE have not inhibitory effect on earnings management before companies listing. Improve earnings management governance, PE team building and monitoring mechanism will help to enhance the positive role of PE to earnings management.
\end{abstract}

Keywords: Earnings management, listed companies, private equity, the GEM.

\section{INTRODUCTION}

Private equity has started relatively later in China. Being an emerging thing in the capital market of China, the private equity (PE) and Growth Enterprise Market, especially the excess return of the private equity investment institutions and the Growth Enterprise Market's "wealth machine" effect, have been aroused wide concern by scholars, regulators and the public consensus. Although the national relevant regulatory bodies made the review mechanism of enterprises' listing increasingly rigorous and comprehensive, there are still some earnings management behaviors that some companies applying for listing made to obtain listing qualification or higher stock issuance price. Being the hot issue of financial accounting theoretical research in the current listed companies, the earnings management has already been widely concerned since the beginning of the seventy's in the last century. In recent years, our national capital market has made considerable progress. The expansion of the stock market scale, especially the opening of Growth Enterprise Market in 2009, opened a new chapter for the study of earnings management in our national earnings management of listed companies. The earnings management is common in the listed companies and brings adverse effects to the normal operation of the market economy; the study of how the private equity investment have impact on the earnings management of Growth Enterprise Market is helpful to know the earnings management status of the listed companies of Growth Enterprise Market so as to promote the standardized operation of the Growth Enterprise Market.

\section{LITERATURE REVIEW}

The research on the earnings management tools. There are two major categories of earnings management tools most commonly used in companies: one is the actual earnings management, that is, to achieve the earnings management goal through the operating decision. The second one is the purely financial reporting decision. Enterprises would make a comprehensive trade-offs according to the cost-benefits of the tools in the choice of what kind of tools they will use. Therefore, enterprises may use an individual earnings management tool or mixed earnings management tools according to different circumstances.

From the aspect of the balance of earnings management, if taking using other earnings management tools at the same time into account, in addition to the usual discretionary accruals items, it may be much more effectively to identify the phenomenon of the earnings management of enterprises. Herrmann et al. (2003) took the Japanese companies as samples, the empirical results showed that when the net management industry profit is lower (higher) than the net operating profit that the management authority predicts, companies will increase (decrease) earnings through the sale of fixed assets and securities. Therefore, in addition to the usual discretionary accruals in the literature, the excess disposal of profit and loss of fixed assets and surplus disposal of profit and loss of investment also need to be considered as the proxy variables of the earnings management.

Regarding the research on the influence of private equity to the earnings management of IPO, the relevant research of Jain and Kini (1995) based on the sample of North American securities market is the representative one that found that the private equity investment's participation of shareholding can significantly improve the company's operating performance and also has positive effect of enhancing the company's management level through the qualitative and quantitative analysis. The study of Lee and Masulis (2011) shows that: the listed companies underwritten by the investment banks of great and prestigious reputation has significantly relatively less earnings management, and the disclosure of information is converged with the intrinsic quality of financial report of 
the issuing companies; on the contrary, the private equity investment shareholding (even venture capital with higher reputation) is difficult to significantly inhibit the issuer's earnings management behavior.

Overall, there are relatively more studies of earnings management currently, but relatively less studies on the impact of private equity investment on the earnings management behavior of the listed companies, and some findings are not consistent, there are even some certain differences. Chen Xiangyou (2010) examined the relationship of the earnings management degree between the venture capital in the small and medium-size enterprise stock market and the invested enterprises before IPO, and found that the enterprises with venture capital shareholdings had lower degree of earnings management before their listing. The study of Gao Lei and Zhang Jie (2008) shows that when the institutional investors participated in the governance of listed companies to some extent, the earnings management of invested companies would be all reduced. Meanwhile, China's is not perfect because of the current, the private equity would push the invested enterprises perform earnings management behavior driven by the high return of investment because of the current not improved national securities market.

\section{THE EMPIRICAL STUDY DESIGN}

\subsection{Theoretical Assumptions}

Usually, the level of earnings management has inverse relationship with the company value, the higher management level the companies have, the smaller its market value is, and the lower equity returns it will be; on the contrary, the lower the level of earnings management, the larger its market value is, the higher equity returns it will be. The private equity has higher risk and longer investment cycle, in theory, it will cost three to five years to exit successfully; in China's securities market, in fact, it requires longer period to achieve the smoothness exit of the investment. From this point of view, the private equity investors will inhibit the earnings management behavior of the "insiders" to make the target listed companies have more stable performance and more stable equity returns. Therefore, the private equity investors have power to supervise the company's major shareholders and managers to protect their own interest, which enhances the earnings quality of listed companies and reduces the company's earnings management behavior to some certain extent.

Hypothesis H1: The private equity investors will effectively inhibit earnings management behavior of enterprises; there are less earnings management behaviors of the enterprises with private equity investment, and lower degree of earnings management, and the reverse is also true.

Hypothesis H2: The quantity of shareholding of private equity investors will affect the behavior of private equity investors; the larger the quantity of shareholding, the larger power of participating in the company governance and content management it will be; taking the long-term consideration of the company in account, it can effectively inhibit the earnings management behavior pf enterprises and make the earnings management degree lower.

\subsection{Selecting Variables}

\subsubsection{Explanatory Variables - Earnings Management (EM)}

Earnings management is a more subtle adjustment for the earnings of company under the premise of not violating laws and regulations and the accounting standards. So it is difficult to find a way to accurately measure the earnings management, currently, the measurement methods of earnings management are still controversial, researchers mainly estimate the company's earnings management through three methods, i.e. accruals separation, specific accruals and distribution and detection of earnings. Accruals separation becomes the most commonly used measurement method to measure the earnings management of the academia, which is a method that divides the discretionary accruals into the normal discretionary accruals and abnormal discretionary accruals by using regression models, and measure earnings management with abnormal discretionary accruals. The empirical study results of the US market show that, the basic Jones model and the amended Jones model can effectively reveal the level of earnings management of listed companies.

There are several measurement methods of accounting earnings quality in the empirical studies; Jones model and the amended Jones model are the more commonly used ones. In this article, it uses the amended Jones model (Dechow, Sloan and Sweeney, 1995) to measure the earnings management and use the cross-section data to estimate it. The model is as follows:

$$
N D A_{t}=\dot{a}_{1}\left(1 / \mathrm{A}_{\mathrm{t}-1}\right)+\dot{a}_{2}\left[\left(\Delta R E V_{t}-\Delta R E C_{t}\right) / \mathrm{A}_{\mathrm{t}-1}\right]+\dot{a}_{3}\left(P P E_{t} / \mathrm{A}_{\mathrm{t}-1}\right)
$$

In the equation, $N D A_{t}$ represents the non-ruling discretionary accruals of year $\mathrm{t}, A_{t-1}$ represents the total assets of year $\mathrm{t}-1, \triangle R E V_{t}$ represents the main business revenue increasing amount of year $\mathrm{t}, \triangle R E C_{t}$ represents the accounts receivable increasing amount of year $\mathrm{t}, P P E_{t}$ represents the fixed assets of year $\mathrm{t}$. The parameters $\dot{a}_{1}, \dot{a}_{2}$ and $\dot{a}_{3}$ in the above equation can be obtained by using the cross-section data according to the following equation:

$$
T A_{t} / \mathrm{A}_{\mathrm{t}-1}=\hat{a}_{l}\left(1 / \mathrm{A}_{\mathrm{t}-1}\right)+\hat{a}_{2}\left[\left(\Delta R E V_{t}-\Delta R E C_{t}\right) / \mathrm{A}_{\mathrm{t}-1}\right]+\hat{a}_{3}\left(P P E_{t} / \mathrm{A}_{\mathrm{t}-1}\right)+\xi_{t}
$$

In the equation, $T A_{t}$ represents the total accruals (equals Net Profits minus the Operating Cash flow) of year $t, \xi_{t}$ is a random error term. And $\hat{a}_{1}, \hat{a}_{2}$ and $\hat{a}_{3}$ are the estimated value of parameters of $\dot{a}_{1}, \dot{a}_{2}$ and $\dot{a}_{3}$ respectively. The total accrual minus the non-ruling discretionary accruals equals the ruling discretionary accruals: $D A_{t}=T A_{t} / \mathrm{A}_{\mathrm{t}-1}-N D A_{t}$; It should be noted that, since in this article, it needs the surrogate marker for the accounting information quality, so it uses the absolute value of $D A_{t}$ to measure the company's earnings management (EM). The relatively higher ruling discretionary accruals mean that the accounting information is untrue and opaque, and the accounting earnings quality will be also relatively worse. 


\subsubsection{Explanatory Variables}

Whether the listed companies have the private equity investment background or not are defined according to the following criteria: If the "private equity investment", "venture investment", "venture capital" and "IPO investment" are contained in the top ten shareholders of the listed companies, it is defined as the company that has a venture capital investment background; in addition, for the companies that have the characters like "high-tech investment", "high and new investment", "innovation investment", "technology investment", "technological transformation investment", "information industry investment", "technology industrial investment", "high-tech stock investment", "high-tech industry investment", "technology investment", "investment company" and "investment Co.Ltd" of the top ten shareholders, it will be further confirmed according to the following two ways: First of all, according to consult and read the list of venture capital companies recorded in "China venture Capital report" which is compiled by the Venture Capital Research Institute of China Science and Technology Development Research Center, if the shareholder is recorded in it, then it will be the listed company of the top ten shareholders with private equity investment background; secondly, search the main business of the shareholders online, if the "venture investment" and "venture capital" are contained in it, then it will be the listed company of the top ten shareholders with venture capital investment background.

\subsubsection{Control Variable}

According to research results of most scholars, assetliability ratio, profitability, asset size, growth rate, along with asset term structure, audit opinion, ownership property, marketization degree and the existence of equity financing, etc. can all serve as the influencing factors for credit and loan availability of an enterprise. Based on the previous research results, the following control variables have been involved in the solid evidences, namely return on total assets (ROA), scale of company(SIZE), company growth (GROW), assetliability ratio(LEV), abundance degree of equity fund(CFIO) and share proportion of the largest shareholder (TOP1).

(1) ROE. ROE refers to the rate of earnings to net asset of an enterprise within a specific period. It serves as not only the core index which reflects the comprehensive utilization result of net asset, but also the key indicator measuring the profitability of enterprise net asset. Hence, ROE is recognized as the measurement of enterprise profitability.

(2) SIZE. In order to control the possible influence of scale of small and medium-sized listed companies on bank's loan policy, the closing total asset (take the logarithm, and smooth the influence of dimension) is adopted as the size control variable. The regression symbol of the index is expected to be positive.

(3) GROW. Growth of an enterprise refers to the increase of enterprise value. In the paper, growth rate of sales revenue is employed to measure the enterprise growth; that is, GROW=(sales revenue of the current year-sales revenue of the last year)/ sales revenue of the last year; the regression symbol of the GROW is expected to be positive.
(4) LEV. the liabilities level of those enterprises will exert important influence on their credit financing. With greater liabilities level, the enterprise is provided with greater operational risk. Hence, LEV is set as the control variable, and LEV symbol is expected to be negative.

(5) $\mathrm{CFIO}$. In the paper, $\mathrm{CFIO}=$ (net cash flow of operational activities- net cash flow of investment activities)/ elimination of influence of dimension by total assets at the beginning the period. For an enterprise, sufficient equity fund can ensure more bank loan, while meanwhile reduce enterprise demand for external finance. Hence, the paper presents no prediction for the regression symbol of CFIO.

(6) TOP1. Control of company property will exert great influence on company behaviors, especially the earnings management situation of the company. In the paper, TOP1 is selected as the control of company property.

\subsection{Model Building}

In the model, the earnings management degree of listed companies is set as explained variable, and existence of venture investment (VC_Dum) is taken as explaining variable. Besides, with relevant control variables, multiple regression equation is constructed to analyze the direction and scale of various influencing factors. The specific model is show as equation (3):

$E M=\hat{a}_{0}+\hat{a}_{1}$ VC_Dum $+\hat{a}_{2}$ Roe $+\hat{a}_{3}$ Size $+\hat{a}_{4}$ RGrow $+\hat{a}_{5}$ Lev $+\hat{a}_{6}$ Cfio $+\hat{a}_{7}$ Top $1+\xi_{t}$

Moreover, the earnings management degree of listed companies is taken as explained variable, and venture investment proportion (VC_Share) is taken as explaining variable. Besides, with relevant control variables, multiple regression equation is constructed to analyze the direction and scale of various influencing factors. The specific model is show as equation (4):

$E M=\hat{a}_{0}+\hat{a}_{1}$ VC_Share $+\hat{a}_{2}$ Roe $+\hat{a}_{3}$ Size $+\hat{a}_{4}$ RGrow $+\hat{a}_{5}$ Lev $+\hat{a}_{6}$ Cfio $+\hat{a}_{7}$ Top $1+\xi_{t}$

\subsection{Sample Selection and Test}

\subsubsection{Sample Selection}

Selected sample in the paper comes from the data of listed companies on GEM. The reason lies in that GEM is a market opened specifically for middle and small-sized enterprises, for which the market offers direct financing platform. The market is developed to provide direct financing platform for middle and small-sized enterprises with outstanding main business, growth power and technological content. Moreover, there is a natural reasonability in the combination of high-growth of start-up enterprises and private equity investment.

In the paper, 355 listed companies on GEM from October 23, 2009 to December 31, 2013 are selected as research object (Jiangsu Hengjiu Group whose listing application has been returned is not counted in) ${ }^{1}$, so as to analyze the influence of private equity investment on the earnings management behavior of listed companies on GEM. Due to the short

1. In October, 2012, When Guangyi Technology (300356)was listed on GEM, the GEM was in the stagnation stage; until January 21, 2014, Wowu Biology (300357) was listed on the GRM. 
Table 1. Descriptive statistics of major variables.

\begin{tabular}{|c|c|c|c|c|}
\hline Variable & Mean Value & Standard Deviation & Minimum Value & Maximum Value \\
\hline \hline EM & 0.0683 & 0.1509 & -0.7746 & 1.0628 \\
\hline VC_Dum & 0.7021 & 0.4580 & 0 & 54.4900 \\
\hline VC_Share & 8.5981 & 9.0734 & 1.0000 & 81.3900 \\
\hline Roe & 31.7519 & 11.6353 & 18.0426 & 21.7794 \\
\hline Size & 19.4587 & 0.5922 & -0.4479 & 9.7563 \\
\hline Grow & 0.4116 & 0.6135 & 4.3100 & 76.2500 \\
\hline Lev & 39.8571 & 14.6373 & -0.2922 & 2.9002 \\
\hline Cfio & 0.3669 & 0.2937 & 6.0000 & 3101.0000 \\
\hline Top1 & 43.3323 & 169.5804 & \\
\hline
\end{tabular}

listing period in terms of listed companies on GEM and that there are no companies in financial industry, there is no need of other treatment for the samples. The data in the paper is acquired from the website (http://www.szse.cn) of Shenzhen Stock Exchange. Moreover, private data is acquired from Zero2IPO Database, while all the financial data come from CSMAR and annual reports of all listed companies on GEM. As for the empirical test and analysis process, measurement software tools of SPSS17.0 and EXCEL2007 are adopted to complete relevant calculation.

\subsubsection{Descriptive Statistical Analysis}

Among the 355 listed companies, there are 177 companies with private equity investment, while the other 178 have no such investment.

First, descriptive statistics is conducted to get a general understanding about the overall characteristics and distribution of all the variables.

\subsubsection{Real Evidence and Analysis}

Table 3 presents the result of Multiple Linear Regression for ModelIand ModelII. Modellaims at testing the hypothesis 1 while ModelIIaims at testing hypothesis 2 . It can be seen that the $\mathrm{F}$ value of both models becomes significant on the 0.01 significance level, which means that the regression models are effective. In terms of the goodness of fit, R2 of Modellis 0.5658 after adjustment, which can explain the $56.58 \%$ of influencing the credit and loan availability. Besides, minimums of the goodness of fit for ModelIIare 0.5686 and 0.5597 , which can explain the $56.86 \%$ and $55.97 \%$ of influencing the credit and loan availability. It can be proved that the two models are provided with great goodness of fit. Hence, both Modelland ModellIhave been well tested, thus are provided with statistical significance.

According to the real evidence result of ModelI, with the significance level of 5\%, the influence of VC_Dum on company's earnings management is negative, with the coefficient being -0.0213 . It means that the introduction of private equity can restrict the earnings management to some extent. It also shows that venture capitalists of the company are the value investors who can govern the company so as to reduce the earnings management level and ensure the realness of accounting information.

According to the real evidence result of ModelII, with the significance level of $1 \%$, shareholding ratio of $\mathrm{VC}$ Dum has a negative correlation with company's earnings management, with the coefficient being -0.1358 . With higher shareholding ratio, earnings management level would be lower. Privateequity firms with higher shareholding ratio means more than financial investors; moreover, highly effective suggestions would be put forward for the company governance and operation. More importantly, company's operation can be monitored, and perfection of company governance can be promoted, thereby reducing the degree of earnings management. Generally speaking, private equity investors with lower shareholding ratio can be late investors, while most of the venture capitalists involved in the company in later period can be speculators. Their investment purpose is to gain many profits after the listing date. This act, however, will raise the earnings management level, thereby promoting the listing and fast high-price cashing.

From the control variable, it can be seen that return on equity has a negative correlation with earnings management. With greater return on equity, the earnings management capacity would be greater. With lower earnings management degree, a company will have weaker earnings management motive in case it is endowed with greater profitability. Besides, scale of the company has a negative correlation with earnings management. The greater the scale is, the weaker the earnings management degree would be. The fact is mainly due to that large companies are provided with complete internal control and thorough rules and regulations, which hinders the operability for earnings management. Moreover, growth of a company has a positive correlation with earnings management degree, which is different from theoretical understanding. Theoretically, the better the enterprise growth is, the weaker that the motive for earnings management would be. However, based on the real evidence result, there is a positive correlation between the two sides. Practically, long growth stage would be the best period for company's earnings management. During the period, the 
Table 2. Empirical analysis result.

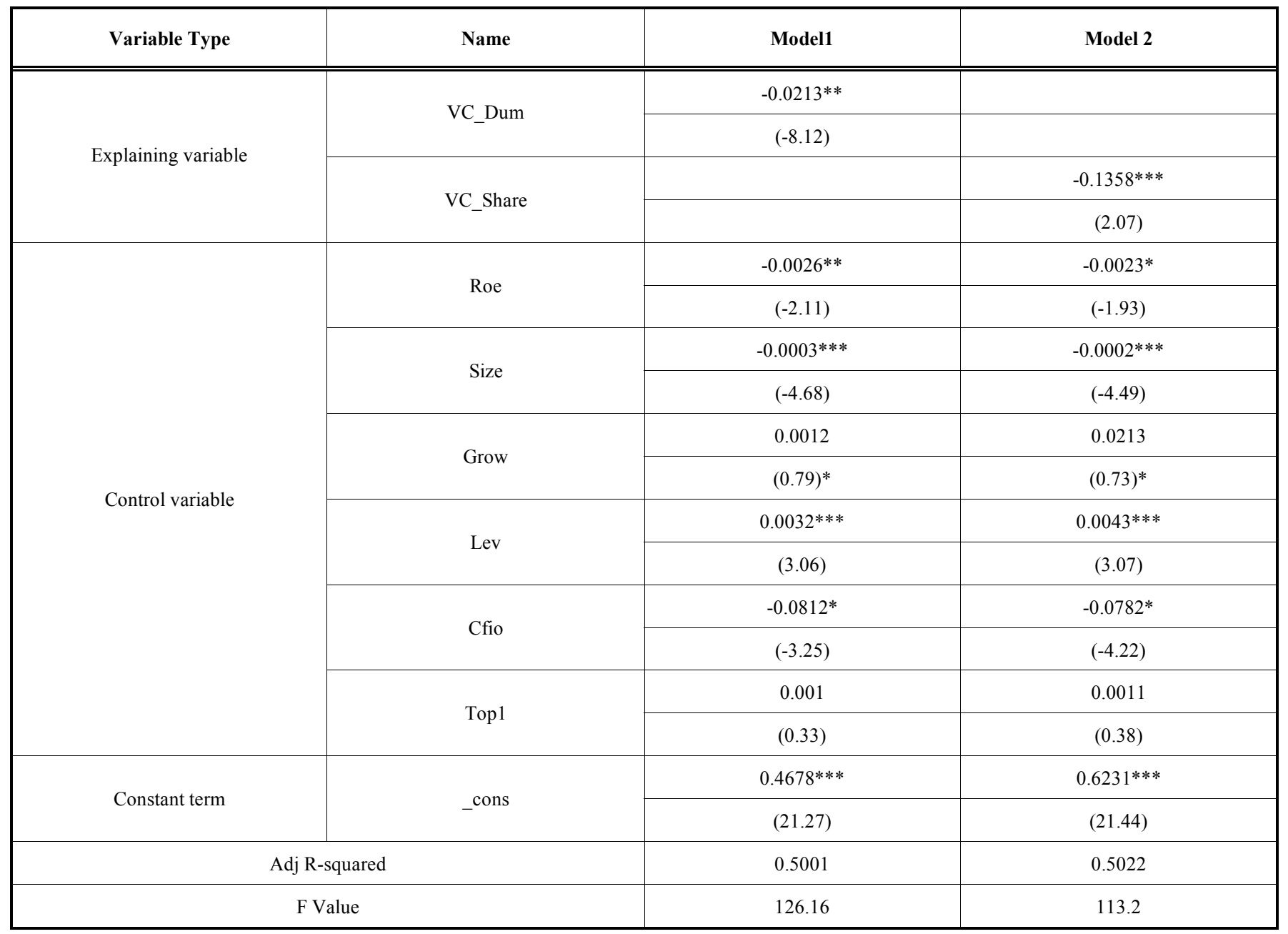

Note: the number in the figure is the regression coefficient of explaining variables, with the number in the corresponding bracket being t value; ${ }^{* * *}$ means significant at the $1 \%$ level, ** means significant at the $5 \%$ level while *means significant at the $10 \%$ level.

company has more businesses, so are the means and ways for earnings management, which will raise the earnings management degree. The leverage ratio has a positive correlation with earnings management degree, while the leverage ratio can reflect the liabilities degree of a company. Companies with higher leverage ratio can be easier to draw the attention of supervisors and stakeholders. Actually, they focus more on the capacity of sustainable development. At this time, a company would always use earnings management to increase the financial index. Furthermore, the abundance degree of equity fund is inversely proportional to company's earnings management. Free cash flow can better reflect the operational situation of a company. The more abundant the free cash flow is, the better the operational indicator will be. In this way, a company has no motivation in venture earnings management. The coefficient of TOP1 is not significant.

\section{RESEARCH CONCLUSIONS AND INSPIRATION}

In the paper, revised Jones model is employed to conduct empirical test on the earnings management level of listed companies on GEM. Moreover, regression model is utilized to analyze the relationship between earnings management degree and private equity investment in terms of all the sample companies. The empirical test results can be shown as:

1. There are universal positive earnings management behaviors among listed companies on GEM, and there is no significant restriction with private equity. Through the revised Jones model, test has been conducted on the influence of private equity exerted on earnings management level of listed companies on GEM. The result shows that, there are universal positive earnings management behaviors among listed companies. However, private equity investment has no significant restricting function for the earnings management level in the previous year of the listed company.

2. To a certain degree, private equity holdings can change the equity structure and corporate governance level, thereby supervising and influencing the earnings management level of the enterprise. The influence can mainly work through company governance and participating in company's internal management.

In general, private equity investment organizations inside China have not played the due supervisory role, which may be caused by short founding period of those private equity 
investment organizations. Besides, the reasons may also include imperfect private equity investment system and access $\&$ exit mechanism for the private equity.

\section{CONFLICT OF INTEREST}

The authors confirm that this article content has no conflict of interest.

\section{ACKNOWLEDGEMENTS}

The authors are grateful to the anonymous referee and the Editor for many helpful comments that greatly improved the paper. The research reported in this paper is supported by the National Social Science of China (project no. 12AZD035), and the National Natural Science Foundation of China (project no.71221001).

\section{REFERENCES}

[1] T. Hellmann, and M. Puri, "Venture Capital and the Professionalization of Start-up Firms: Empirical Evidence," Journal of Finance, vol. 57, pp. 169-197, 2002.

[2] G. Lee, and R.W. Masulis, "Do more reputable financial institutions reduce earnings management by IPO issuers", SSRN working paper, 2011.
[3] S.G. Morsfield, and C.E.L. Tan, "Do venture capitalist influence the decision to manage earnings in initial public offerings?" Accounting Review, vol. 81, pp. 1119-1150, 2006.

[4] Z. Zhang, and Y. Li, "Why do ChiNext board firms accept private equity shortly before IPO? Empirical research on trade-off perspective," The Ninth China International Conference in Finance, Wuhan) First prize on PhD Forum, 2011.

[5] L. Gao, and J. Zhang, "Corporate Governance, Institutional Investors, and Earnings Management," Accounting Research, vol. 9, pp. 23-28, 2008.

[6] X. Chen, "Empirical research on the relationship between venture investment and earnings management of IPO companies," Research on Financial and Economic Issues, vol. 1, pp. 15-23, 2010.

[7] L. Suo, and K. Yang, "Empirical Study on Venture Investment and Earnings Management of IPO: Based on GEM Listed Compan," Academic Journal of Nanjing Audit University. vol.4, pp.45-50, 2011

[8] P.M. Dechow, R. G. Sloan, and A.P. Sweeney, "Sweeney. Detecting Earnings Management," Accounting Review, vol.70,pp. 193225,1995 .

[9] J.J. Kao, Z. Wu, and F. Yang, “Regulations, earnings management, and post -IPO performance: The Chinese evidence" Journal of Banking and Finance, vol.33, pp.63-76, 2009.

[10] G. John and W. Mike, "Private Equity Demistified: Second Edition" An initiative from the ICAEW Corporate Finance Faculty, 2010 .

(C) He and Liao; Licensee Bentham Open.

This is an open access article licensed under the terms of the Creative Commons Attribution Non-Commercial License (http://creativecommons.org/licenses/by-nc/3.0/) which permits unrestricted, non-commercial use, distribution and reproduction in any medium, provided the work is properly cited. 